\title{
Dünya ve Türkiye'de Otizmle İlgili Çalışan Kar Amacı Gütmeyen Örgütlerin Web Sitelerinin Halkla İlişkiler Perspektifinden Karşılaştırmalı İncelemesi
}

\author{
DOI: $10.26466 /$ opus.541151 \\ *
}

\author{
Nilay Başok*- Gül Coşkun Değirmen**- Miraç Pınar Mert ${ }^{* * *}$ \\ *Prof. Dr, Ege Üniversitesi, İletişim Fakültesi, Bornova / İzmir / Türkiye \\ E-Posta: nilay.basok@ege.edu.tr \\ ORCID: $\quad$ 0000-0002-4481-5725 \\ ** Doç. Dr., Ege Üniversitesi, İletişim Fakültesi, Bornova / İzmir/ Türkiye \\ E-Posta: coskungul@gmail.com \\ ORCID: $\quad$ 0000-0001-7535-2754 \\ *** Yüksek Lisans Öğr., Ege Üniversitesi, İletişim Fakültesi, Bornova / İzmir / Türkiye \\ E-Posta: miracpinar@gmail.com \\ ORCID: $\quad$ 0000-0003-2148-1440
}

\begin{abstract}
Öz
Çalışma kapsamında ilk olarak halkla ilişkiler alanında web sitesi kullanımına değinilmiştir. Daha sonra otizmle ilgili çalışan örgütlerin web sitelerinin halka ilişkiler perspektifinden nasıl kullanılması gerektiğgi ortaya konulmuş ve bu alandaki çalışmalara değinilmiştir. Araştırma kısmında ise dünyada otizm konusunda faaliyet gösteren World Autism Organisation'a resmi olarak üye olan Türkiye'de faaliyet gösteren Otizm Dernekleri Federasyonu (ODFED), WAO'nun ortaklarından Autism Society, ODFED'in destekçisi Tohum Otizm Vakfı belirlenmiştir. Ayrıca kıyas amaçlı olarak; Avrupa'da aktif olarak faaliyet gösteren merkezi Belçika'da yer alan Autism Euorope ve Türkiye'den ise Anadolu Otizm Vakfı web sitesi araştırılmıştır. Dünyada ve Türkiye'de otizmle ilgili aktif olarak çalışan altı örgütün tanıtım ve bilgilendirme misyonlarını, web siteleri aracilğ̆ıla nasıl gerçekleştirdikleri, web sitelerinde görsel-işitsel ögeleri nasıl kullandıkları, kendileri hakkındaki bilgileri sitelerin hedef kitlesine nasıl yansittıklar ve hedef kitlelerine internet ortaminda ne tür imkânlar sundukları karşılaştırmalı bir şekilde araştırılmıştır. Kıyaslamalı olarak elde edilen verilerle, ülkemizde otizmle ilgili çalışan Tohum Otizm Vakfı, Otizm Dernekleri Federasyonu, Anadolu Otizm Vakfi'nın eğitimleri ve kamuoyunu bilinçlendirme amaçl çalışmalarının geliştirilmesi amaçlanmaktadır.
\end{abstract}

Anahtar Kelimeler: İnternet, Web Sitesi, Otizm, Sivil Toplum Örgütü 


\title{
The Web Sites of Nonprofit Organizations That Deal with Autism in The World and Turkey: A Comparative Study from The Perspective of Public Relations
}

*

\begin{abstract}
In the scope of the study, firstly the use of the website in the field of public relations is explained. After this, it shows how to autism organizations websites use perspective by public relations. In the part of literature, the study has focused on how organizations which work in autism can be more effective in their websites. In the research part of study Federation of Autism Associations which takes place in Turkey and the official member of World Autism Organization, Autism Society which the member of World Autism Organization, and Tohum Autism Association (the supporter of Federation of Autism Associations) has been examined as sample. However, Autism Europe's which takes place in Belgium and Anatolian Foundation of Autism's (ANOVtakes place in Turkey) websites have been chosen for comparing study and gathering different data. In this study how six organization working hard about autism in the world and Turkey do it through web sites about promotion and information missions, how they use audiovisual elements on websites, how they reflect the information about themselves to their target audience and what kind of opportunities they offer to the target audiences on the internet have researched. And then compared this NGO's.
\end{abstract}

Keywords: Internet, Website, NGO 


\section{Giriş}

Enformasyon toplumuyla birlikte bilginin değişen içeriği ve yapısı toplumsal hayatın da değişikliğe uğramasına neden olmaktadır. Bu değişiklik kültürel, sosyal ve ekonomik alana kadar uzanmaktadır. Küreselleşen dünyada bilginin değişen yüzü doğrultusunda yeni araçların ortaya çıkması söz konusu olmakta ve internet ise bu araçlardan biri olarak karşımıza çıkmaktadır. Bilgi iletişim teknolojilerinin getirdiği internet kullanımı, bazı sektörlerin değişimini biraz daha hızlandırmıştır. Halkla ilişkiler, bu değişime hızlı bir biçimde ayak uydurmak durumunda olan sektörlerin başında gelmektedir. Bu durum, halkla ilişkiler alanının da değişim göstermesine sebep olmuştur. Örgütler, tanıma ve tanıtma faaliyetlerini web siteleri üzerinden yapmaktadır.

İnternetin halkla ilişkilere sağladığı avantajlar konusunda birçok akademisyen hemfikirdir. Bu avantajlardan en önemlisi ise web ortamında karşıllklı iletişim/diyalog kurulabilmesidir. Hedef kitlelerin beklentileri doğrultusunda hareket eden örgütler, bu avantajı iyi değerlendirdikleri takdirde istedikleri imaja ve itibara sahip olmak yönünde de bir avantaj sağlamaktadır. Bunların yanında sanal ortamın sağladığı olanaklar, özellikle kâr amacı gütmeyen örgütler açısından seslerini duyurma, hedef kitleleriyle karşıllıklı etkileşime girme açısından önem taşımaktadır.

Sağlık, eğitim, çevre vb. birçok konuda gün geçtikçe daha fazla çalışma gerçekleştirme ihtiyacı doğmakta, internet ile bu konularda dünyanın her yerindeki ihtiyaçlar daha hızlı yayılabilmektedir. Otizm de bu konular içinde yer alan ve günümüzde gerek ulusal gerekse uluslararası alanda üzerine birçok proje gerçekleştirilen önemli bir alan olmuştur. "Amerikan Hastalıkları Kontrol Etme ve Önleme Merkezinin (Centers for Disease Control Prevention) 2014 verilerine göre dünya genelinde doğan 68 çocuktan 1'i otizm teşhisi almaktadır" (http://www.odfed.org) Otizm gün geçtikçe artmaya devam etmektedir. Bununla ilgili Türkiye Bilimsel ve Teknolojik Araştırma Kurumu'nun web sitesinde "1985 yılında her 2500 çocuktan birine konan otizm tanısı, 2001 yılında 250, 2013 yılında 88 çocuğa konurken, günümüzde her 68 çocuktan biri otizmli olarak dünyaya geliyor" (http://www.bilimgenc.-tubitak.gov.tr) denilmektedir. Diğer bir habere göre; Türkiye Engelliler Konfederasyonu Yönetim 
Kurulu üyesi Besim Toker, “...2030 yılında her dört doğumdan birinde bebeğin Otistik olarak dünyaya gelmesi bekleniyor" demiştir. (http://t24.com.tr). Konunun gelecek açısından ne kadar önemli olduğu medyada da yer almaktadır. Geleneksel ve yeni medyada, otizmle ilgili farkındalık çalışmalarının yer aldığı görülmektedir. Ancak bu mecralarda yapılan çalışmaların mesaj içerikleri birbirinden kopuk şekilde hedef kitlelere sunulmaktadır. Böyle önemli bir sorunun bütünsel olarak ele alınması ve güncelliğini koruması açısından web siteleri üzerinden yapılacak çalışmaların detaylarının ve eş zamanlılığının olması, konunun duyurulması ve farkındalık açısından başarı oranını attırmaktadır. Sorunun önemi karşısında otizmle ilgili çalışan sivil toplum örgütlerinin web sitelerini; farkındalık, bilinçlendirme, eğitim olanaklarının öğrenilmesi, sosyal destek sağlama bağlamında kullanmaları gerekmektedir. $\mathrm{Bu}$ doğrultuda hedef kitlelerini iyi bir şekilde tanımlamaları kitlesel hareketi başlatma ve bilgilendirme adına büyük bir öneme sahiptir. Aynı zamanda Tohum Otizm Vakfı, Otizm Dernekleri Federasyonu (ODFED), Anadolu Otizm Vakfı'nın (ANOV), World Autism Organisation (WAO), Autism Europe, Autism Society gibi sivil toplum örgütlerinin, web sitelerinde bulundurdukları belirli özellikler kurumun güvenilirlik, itibar ve imajı konusunda da hedef kitleleri bilgilendirmektedir.

$\mathrm{Bu}$ araştırma kapsamında; halkla ilişkiler ve tanıtım faaliyetlerinin interneti ve web sitelerini bir araç olarak nasıl kullandığının değerlendirilmesi yapılmış, araştırmanın amacına uygun olarak otizmle ilgili çalışan örgütlerin halkla ilişkiler perspektifinde, web sitelerini nasıl kullandıkları konularına yer verilmiştir. Araştırmanın uygulama bölümünde ise dünyada faaliyet gösteren World Autism Organisation (WAO), Autism Society, Autism Europe, Türkiye'de faaliyet gösteren Tohum Otizm Vakfı, Otizm Dernekleri Federasyonu (ODFED) ve Anadolu Otizm Vakfı'nın (ANOV) web siteleri halka ilişkiler kullanımları açısından karşılaştırmalı olarak değerlendirilmektedir.

\section{İnternet Ortamında Halkla İlişkiler Kullanımı}

Küreselleşen dünyada, bilginin değişen yapısının beraberinde getirdiği bilgi iletişim teknolojileri kavramıyla birlikte bireylerin günlük yaşamları 
da değişikliğe uğramıştır. Bu değişiklik sosyal, politik, ekonomik olmak üzere hayatın her alanını etkilemektedir. Bilgi iletişim teknolojileri kavramı, beraberinde başka kavramları da getirmektedir. İnternet bu kavramlardan birisidir. İnternet kullanımıyla birlikte hem bireysel bazda hem de örgütler bazında büyük oranda değişimler olmuştur. Bu değişimlerin en önemlisi bilgiye ulaşılabilirlik kapsamında küreselleşen dünyanın yerelleşmesidir. İnternetin getirdiği avantajlardan en önemlisi ise bilgiye anında ve hızlı bir şekilde ulaşılması olarak karşımıza çıkmaktadır. Bu durum, bazı sektörler açısından daha da önemli hale gelmektedir. Halkla ilişkiler bu sektörlerin başında gelmektedir.

Enformasyon toplumunun getirdiği yeni içerikle birlikte yaşanan değişimler halkla ilişkiler mesleğini ve halkla ilişkiler uzmanlarını büyük ölçüde etkilemiştir. Değişen içerik toplumun önceliklerinin de değişmesine neden olmuştur. Bu durum halkla ilişkiler açısından toplumun önceliklerinin değişimine göre hareket etme ve bu duruma duyarlı olma zorunluluğunu beraberinde getirmektedir (Gölönü, 2006, s.76).

İnternetin karşıllklı iletişime olanak vermesi, halkla ilişkilerde kullanımı açısından büyük önem taşımaktadır. İletişimde önemli bir kavram olan geribildirim, halkla ilişkiler açısından daha da önem arz ermektedir. Halkla ilişkilerde tanıma ve tanıtma iki önemli fonksiyon olarak karşımıza çıkmaktadır.

Halkla ilişkiler uzmanları ve araştırmacıları tarafından giderek daha etkin şekilde kullanılması beklenen internet ve web teknolojileri kurumsal bilgi haberleri duyurmadan, kamuoyu araştırmalarına kadar uzanan bir alanda etkili, süratli çözümler üretmede kullanılabilecek iletişim ortamını yaratmaktadır. İnternet özellikle halkla ilişkiler alanında sürekli altı çizilen 'karşılıklı iletişim' unsurunu karşılayan iletişim aracıdır (Balay, 2002, s.849).

İnternet kullanım oranının arttı̆gı günümüzde, hedef kitlelere ulaşabilmek, hedef kitleyi tanımak ve tanımlamak daha kolay bir hale gelmiştir. Örgütler seslerini duyurmak, belirledikleri stratejileri ve hedefleri gerçekleştirebilmek adına internetin olanaklarını doğru zaman ve doğru yerde kullandıkları takdirde hem daha geniş hedef kitlelere ulaşma hem de kurumsal imaj ve itibarlarını istedikleri gibi gerçekleştirme imkânına sahip olacaklardır. Halkla ilişkiler faaliyetlerinin 
zemininde yatan, daha geniş hedef kitlelere kısa sürede ulaşmak kaydıyla tanıma ve tanıtma amaçlarını gerçekleştirmek olduğu düşünülünce, internetin halkla ilişkiler açısından kullanımının neden önemli olduğu daha iyi anlaşılacaktır (Kaplan, 2009, s.86-87).

Gelişen ve değişen yeni teknolojilerin başında gelen internetin halkla ilişkilere sağladığ 1 avantajlar konusunda birçok akademisyen hemfikirdir. Bireye, bilgiye kısa sürede ulaşma imkânı sağlaması, bireyleri daha aktifleştirmesi halkla ilişkiler uygulamalarında yapılacak çalışmaların iletilmesi ve bireylerin nasıl tepkiler verdiklerinin öğrenilmesi açısından avantajlar sağlamaktadır (Tarhan, 2007, s.79). Güçdemir ise avantajları şu başlıklar altında toplamıştır: "birebir iletişimin sağlanması, ölçülebilir olması, güncellenebilir olması, ekonomik olması, kurumsal imaj"dır (Güçdemir, 2002, s.390-391).

Sağladığ1 avantajlar, internetin kullanılmasını örgütler nezdinde önemli bir noktaya taşımaktadır. İnternet ortamının araçsal bir zenginliğe sahip olması, örgütlere sinırsız bilgi depolama, hedef kitle bazında ise sınırsız erişim olanağı sunmaktadır. Örgütler bu ortamı stratejik olarak iyi yönettikleri takdirde iç ve diş hedef kitlelere ulaşabilmeleri daha kolay olacaktır.

Halkla ilişkiler mesleğini icra edenler internet ortamını iyi bir şekilde gözlemleyerek, hedef kitlelerinin örgütleri hakkındaki fikirlerini öğrenip buna göre uygun bir strateji belirleyebilmekte ve olası krizlere çözüm üretmede daha aktif davranabilmektedir (Taş ve Kestellioğlu, 2011, s.83). Aynı zamanda bu durum, örgütlerin kurumsal itibar ve kurumsal imajlarını olumlu yönde geliştirmeleri açısından büyük önem taşımaktadır. Örgütlerin halkla ilişkiler projeleri de bu noktada önemlidir. Geleneksel halkla ilişkilerde olduğu gibi buradaki projelerde de araştırma, planlama, uygulama ve değerlendirme basamakları yer almaktadır.

Gerçekleştirilecek projeler sağlam bir araştırma temelinde oluşturulmalı, yapılacak planlama ve uygulamalar hedef kitle beklentilerini uygun şekilde ortaya konulmalıdır. Geleneksel halkla ilişkiler de olduğu gibi web ortamında gerçekleştirilen her uygulamanın ölçümleme ve değerlendirmesi yapılarak sürekli güncellenmeli ve daha etkin bir hale getirilmelidir (Başok ve Değirmen, 2014, s.170). Geleneksel medyaya oranla birçok avantajı bulunan internet ortamı, birçok araç 
kullanarak halka ilişkiler alanına dâhil olmuştur. Bu araçlardan bazıları; web siteleri, e-posta, haber grupları, dosya transferi, sosyal medya araçları vb. şeklinde kendini göstermektedir.

\section{Halkla İlişkiler Alanında Web Sitelerinin Kullanımı}

"WWW (world wide web) ya da kisaca web internet üzerinden verilerin kolay ve etkili bir şekilde değişmesine imkân veren bir sistemdir" (Güçdemir, 2002, s.391). Web siteleri örgütlerin adeta bir aynası görevini üstlenmektedir. İnternetin sağladığı olanaklardan biri olan web siteleri kullanımının geleneksel halkla ilişkiler faaliyetlerine kıyasla birçok avantajı bulunmaktadır.

İnternet ve web'in birleşmesi hem teknik hem sosyal açıdan benzersiz bir olgu yaratmıştır. Teknik açıdan, bilginin çıkış ve varış noktasını gözetmeksizin herhangi bir mesafeden güvenilir, açık erişim sağlamaktadır; gerçek zamanlı, yüksek bant genişliği olan verilerin nispeten düşük maliyetle karasal olan veya olmayan her noktaya iletilmesine olanak tanımaktadır (Özel ve Sert, 2015, s.8).

İletişimde çok önemli bir yere sahip olan diyalog olanağının internet sayesinde arttığ 1 görülmektedir. Bu durum örgütlerin hedef kitlelerine daha kolay ulaşmaları ve karşılıklı bilgi alışverişi sayesinde kendilerini hedef kitlenin beklentileri doğrultusunda geliştirebilmelerine olanak sağlama konusunda önemlidir.

Örgütlerin imajının geliştirilmesi ve yansıtılması fonksiyonlarının yerine getirilmesini sağlayan web sitelerinin, hedef kitlelerin bilgi ihtiyacını karşılayabilecek geniş bir bakış açısı çerçevesinde oluşturulmuş içerik ve hedef kitlelerin memnun kalmasını sağlayacak kullanışlı bir ziyaretçi arayüzüne sahip olması gerekmektedir. Bu nedenle, web sitesinin görsel olarak zengin, hedef kitlelerin beklentilerine karşılayıcı ve kolay kullanılabilir olması önemlidir (Yeygel ve Temel, 2006, s.223)

Örgütlerin hedef kitlesi ile buluşma noktası olan web siteleri, örgütlere hedef kitlelerine kendilerine tanıtmak adına 24 saat sınırsız, ekonomik, ulaşımı kolay bir hizmet sunmaktadır. Bu hizmet iyi bir şekilde değerlendirildiği takdirde, hedef kitlelerine ulaşabilecek, hedef ve stratejileri doğrultusunda seslerini rahatlıkla duyurabileceklerdir. Bunun gerçekleşmesi için örgütlerin web sitelerinde geri bildirim indeksi 
fonksiyonlarının (e-posta ile iletişim kurabilme, ziyaretçi defteri ya da anketi, istek ve öneri formları vb.) yer alması büyük önem taşımaktadır. "Geri bildirim sağlamayan bir kurumsal web sitesi, yalnızca tanıtım amaçlı elektronik kurumsal broşür işlevi üstlenecektir" (Sayımer, 2012, s. 73). Bu fonksiyon, kurumsal imajin geliştirilmesi ve kurumsal itibar açısından birincil öneme sahiptir.

Web siteleri örgütlerin tanıma ve tanıtma faaliyetlerinde kullanılmaktadır. Hedef kitlelerin örgütü daha iyi tanıması ve örgütün sesini duyurması açısından bu faaliyetler önemlidir. Örgütlerde web sitelerinin kullanım alanları; medya kuruluşlarına bilgi sağlamak, tüm hedef gruplarla günü gününe iletişim kurmak, farklı hedef gruplar hakkında bilgi toplamak, kurum imajını geliştirmek, kurum kimliğini güçlendirmek, çalışanlarla iletişimi sağlamak, bir kuruluş için statü sembolü oluşturmak, online satış yapmak, uluslararası pazarlara ulaşmak, internette gezinen bir kişiye ulaşmak vb. şeklinde siralanmaktadır (Okay ve Okay, 2001, s.669-670).

Web sitelerinin kullanım alanları, kurumlara göre farklılık göstermektedir. Kâr amacı güden kurumlar ile kâr amacı gütmeyen kuruluşların web sitelerini kullanmalarında farklılıklar olabilmektedir. Ancak her ikisinde de tanima ve tanitma faaliyetlerinde kurumsal imajin geliştirilmesi ve yansıtılması, kurumsal itibarın gerçekleştirilmesi ve örgüte duyulan güvenin oluşturulması açısından önem taşımaktadır.

\section{Otizmle İlgili Çalışan Kar Amacı Gütmeyen Kuruluşların Web Sitelerinde Halkla İlişkiler Kullanımı}

Otizm, "doğuştan gelen ya da yaşamın ilk yıllarında ortaya çıkan karmaşık nörogelişimsel bir bozukluk" olarak tanımlanmaktadır. (https://www.tohumotizm.org.tr). Otizmin nedenleri konusunda yapilan çalışmalar halen devam etmekte olup kesin bir bilgiye ulaşılamamaktadır. Ancak otizmin ülkemizde ve dünyada gittikçe artan bir ivmeyle yayıldığ yapılan bilimsel araştırmalar ve raporlarda sunulmaktadır. "Amerikan Hastalıkları Kontrol Etme ve Önleme Merkezinin (Centers for Disease Contol Prevention) 2014 verilerine göre dünya genelinde doğan 68 çocuktan 1'i otizm teşhisi almakta ve erkek çocuklarda kız çocuklara oranla yaklaşık 4 kat daha fazla görülmektedir" (http://www.odfed.org). 
Bu veriler 1şığında otizmin ülkemizde ve dünyada çok önemli bir sorun olduğu görülmektedir.

Otizmde erken tanı, eğitime başlama ve sosyal becerilerin geliştirilmesi açısından büyük önem taşımaktadır. Aynı zamanda otizmli çocuğa sahip olan ailelerin yaşadıkları sıkıntı ve stres toplumun en küçük birimi olan ailelerin parçalanmasına, depresyon, anksiyete gibi problemlere sebep olabilmektedir. Otizmli ailelerin yaşadıkları stres, sıkıntılara ve yaşam tarzlarının zorlukları üzerine yapılan birçok bilimsel araştırma bulunmaktadır. $\mathrm{Bu}$ araştırmalarda sosyal destek kavramının önemi vurgulanmaktadır. Sosyal destek içinde; arkadaş desteği, OBS olan çocuklarının ailelerinin birbirlerine verdikleri destek, eğitimci desteği, eşlerin birbirine olan desteği gibi başlıklar yer almaktadır. (Yassıbaş, 2015, s.120). Sosyal destek kavramının içine, devlet desteği, toplum desteği vb. gibi daha birçok destek çeşidi girebilmektedir.

Otizmin erken dönemde fark edilememesi ancak erken teşhisin bir o kadar da önemli oluşu, otizmli çocuğa sahip olan ailelere destek verilmesi, otizmin Dünyada ve Türkiye'de gittikçe artan bir ivmeyle yayılması, sorunun fark edilmesi, duyurulması açısından konuyu önemli bir konuma getirmektedir. Bu noktada otizmle ilgili çalışan kâr amacı gütmeyen örgütlere büyük iş düşmektedir. İnternet ortamının araçlarından olan web siteleri aracılığıyla bu örgütler hem kendi tanıtımları hem de otizme yönelik tanıtım ve tanınmayı gerçekleştirme olanağına sahip olmaktadırlar.

Otizmle ilgili çalışan ve kâr amacı gütmeyen örgütlerin birincil hedefleri doğrultusunda, hedef kitleleri ile sürekli olarak etkileşim halinde olması, hedef kitlelere yönelik bilinçlendirici ve eğitici içerikleri paylaşması ve internet ortamını aktif bir biçimde kullanması gerekmektedir. Ancak bu şekilde kitlesel hareketleri başlatmaları mümkün olacaktır. (Kaplan, 2009, s.78). Kitlesel hareketlerin başlaması toplumda farkındalığın oluşması açısından büyük bir öneme sahiptir.

Otizmle ilgili çalışan örgütlerin, web sitelerini aynı zamanda bağış̧̧ı ilişkileri bağlamında fon sağlama aracı olarak kullandıklarına rastlanmıştır. Bu örgütlerin web sitesi üzerinden bağış almaları ile kurumsal imaj ve itibarın doğrusal bir ilişki içinde olduğu söylenebilir. Özellikle örgütlerin web sitelerinde kurum kültürü içinde yer alan temel değerler, vizyon, misyon, logo, amblem vb. unsurların yer alması ve 
doğru kelimelerle ifade edilmesi hedef kitlenin örgüte yönelik güvenirliliğini arttıracaktır. Güvenirliliğin bu denli önemli olmasının nedenleri arasında bu örgütlerin web sayfalarını fon sağlama aracı olarak da kullanmaları ve yürütmüş oldukları halkla ilişkiler faaliyetlerinin hedef kitleye ulaşması yer almaktadır.

Örgütün yönetiminde yer alan kişilerin fotoğrafları, iletişim bilgileri, bulundukları birimler hakkında web sitesinde bilgi verilmesi, hedef kitlelerin zihninde kurumsal imaj ve itibarın bir parçası olarak şekillenmektedir. Bu verilerin web sitesinde yer alması örgütlerin tanıtma faaliyetine de katkı sağlamaktadır. Otizmle ilgili çalışan örgütlerin web sitelerinde e-posta ile iletişim kurabilme özelliği ve sosyal destek bağlamında diğer üyelerle iletişime geçme önemlidir. Bu örgütlerin web sitelerinde yer alan eğitim seçenekleri ve otizmin iyi bir şekilde tanımlanması ve bu konuda nasıl bir yol haritası izleyecekleri hem otizmli çocuğu olan aileler hem de toplum açısından önem taşımaktadır.

Otizmle ilgili çalışan örgütlerin hedef kitle tanımlaması, konunun öneminin vurgulanması ve farkındalığın arttırılması açısından önemlidir. Farkındalık kampanyalarının iyi bir şekilde duyurulması noktasında büyük öneme sahip olan web sitelerini stratejik olarak iyi kullanan örgütler misyonlarına ve hedeflerine ulaşabileceklerdir. Bu denli önemli bir sorunun duyurulması konusunda otizmle ilgili çalışan örgütlerin web sitelerine bilinçlendirme, kitlesel hareketi sağlama, destek verme noktasında toplumsal bir sorumluluk yüklenmektedir.

\section{Araştırma}

\section{Araştırmanın Amacı}

Günümüzde önemli bir sorun haline gelen otizm konusu geçmiş yıllardan bu yana büyük bir ivmeyle artış göstermektedir. Otizmin erken dönemde fark edilememesi ancak erken teşhisin ve eğitimin önemli oluşu sorunun duyurulması, iyi bir şekilde tanımlanması, eğitim olanaklarının neler olduğunun açıkça belirtilmesi ve farkındalık çalışmaları, otizmle ilgili çalışan örgütlerin hedefleri arasındadır. Bu örgütlerin bu hedefleri gerçekleştirebilmeleri için hedef kitlelerini iyi tanımlamaları gerekmektedir. Günümüzde web siteleri, örgütlerin halkla ilişkiler 
faaliyetlerini gerçekleştirme ve hedef kitlelerine, paydaşlarına ulaşma konusunda oldukça önemli bir noktaya gelmiştir. Bununla bağlantılı olarak otizmle ilgili çalışan örgütlerin web siteleri, hedef kitlelerine ulaşma ve seslerini duyurma konularında oldukça önemli bir hale gelmektedir. Bu bağlamda otizmle ilgili çalışan örgütlerin içeriklerini web sayfaları aracılığı ile hedef kitlelerine aktarımının ne şekilde sağlandığ 1 araştırmanın temel amacını oluşturmaktadır. Araştırmanın diğer amacı, otizmle ilgili çalışan örgütlerin web sitelerinin; otizmin tanımı, eğitimi, istihdam olanakları, sosyal destek, farkındalık konusunda bilgiyi yaymaları noktasında hedef kitlelere ulaşmaları, görsel ve içeriksel olarak web sayfalarını halkla ilişkiler perspektifinden nasıl kullandıklarını, dünya ve Türkiye örnekleri üzerinden karşılaştırmalı olarak ortaya koyabilmektir.

\section{Araştırmanın Evreni ve Örneklemi}

Araştırmada evren olarak dünyada otizm konusunda faaliyet gösteren World Autism Organisation ele alınmıştır. Araştırmanın örneklemi olarak ise; World Autism Organisation'a resmi olarak üye olan Türkiye'de faaliyet gösteren Otizm Dernekleri Federasyonu (ODFED), WAO'nun ortaklarından Autism Society, ODFED'in destekçisi Tohum Otizm Vakfı belirlenmiştir. Ayrıca kıyas amaçlı olarak; Avrupa'da aktif olarak faaliyet gösteren merkezi Belçika'da yer alan Autism Euorope ve Türkiye'den ise Anadolu Otizm Vakfı web sitesi araştırılmıştır. Siteler, 1.12.2017 01.02.2018 tarihleri arasında incelenmiştir.

\section{Araştırmanın Yöntemi}

Otizmle ilgili çalışan örgütlerin web site analizinde Gibson, Margolis, Resnick ve Ward'un "Election Campaigning On The WWW In the US And The Uk: A Compatative Analysis" (Gibson, R; Margolis M., Resnick D. \& Ward S., 2001) adlı makalesinde kullandıkları araştırma yöntemi temel alınmıştır. Analiz çerçevesinde örgütlerin web sitelerinin kurumsal tanıtım açısından incelenmesinde fonksiyon ve sunum özelliklerinden faydalanılmıştır. Web sitelerinin enformasyon/bilgi akışı, haberleşme ağı, katılımcılık ve kampanya fonksiyonları, görsellik, erişebilirlik, 
gezilebilirlik ve görülebilirlik indeksleri değerlendirilmiştir. Otizmle ilgili çalışan örgütlerin web sitelerinin incelenmesinde yine Gibson, Margolis, Resnick ve Ward'un geliştirdikleri alt indeksler ve puanlama sistemi uygulanmıştır. Söz konusu yöntem otizme yönelik olarak uyarlanmıştır.

\section{Araştırma Bulguları}

\section{1) Web Sitelerinin Fonksiyon Özellikleri}

Araştırma kapsamında yer alan otizmle ilgili vakıf, örgüt ve toplulukların web siteleri fonksiyon özellikleri; enformasyon/bilgi akışı, haberleşme ağı, katılımcılık ve kampanya bağlamlarında incelenmiştir. Veriler aşağıda yer alan tabloda sunulmaktadır.

Tablo 1. Web Sitelerinin Fonksiyon Özellikleri.

\begin{tabular}{lcccc}
\hline & $\begin{array}{c}\text { Enformasyon } \\
\text { Akışı }\end{array}$ & $\begin{array}{c}\text { Haberleşme } \\
\text { A ̆ğ }\end{array}$ & Katılımcılık & Kampanya \\
\hline Tohum Otizm Vakfı & 16 & 3 & 4 & 4 \\
Autism Society & 15 & 6 & 7 & 4 \\
ODFED & 12 & 4 & 6 & 3 \\
World Autism Organisation & 10 & 4 & 4 & 3 \\
ANOV & 13 & 2 & 3 & 2 \\
Autism Europe & 14 & 4 & 5 & 4 \\
Ortalama & 13,3 & 3,8 & 4,8 & 3,3 \\
Aralık & $0-18$ & $0-10$ & $0-8$ & $0-4$ \\
\hline
\end{tabular}

Enformasyon/Bilgi Akışı Fonksiyonu: Araştırmanın örneklemini oluşturan 6 web sitesinin hepsinde kurumsal tarihle ilgili veriler bulunmaktadır. Kurumun vizyonu ve misyonu ile ilgili bilgiler, Tohum Otizm Vakfı ve Autism Society'de hakkında kısmında bulunurken, World Autism Organisation'ın ise amaç ve hedefler başlı̆̆ı altında yer almaktadır. ODFED'in web sayfasında ise bu konuyla ilgili bilgi bulunmamaktadır. Diğer web sitelerinde ise vizyon ve misyon bir menü seçeneği olarak bulunmaktadır. Vakıf, topluluk ve örgütlerinin içinde nasıl bir iş bölümünün yapıldığı bilgisini sunan seçenek araştırma bağlamında incelenen tüm web sitelerinde bulunmaktadır.

Vakıf, örgüt ve toplulukların sözcüsü veya liderinin mesajı seçeneği Tohum Otizm Vakfı, Autism Society, ODFED, ANOV ve Autism Europe 'da yer almazken, World Autism Organisation 'da "Neden Katılmalıyı" 
seçeneği içinde (direk buton olmadığı için puanlandırılmaya alınmamıştır) yer almaktadır. Üyelik işlemleri ile ilgili bilgiler ve seçenek incelenen tüm web sitelerinde yer almaktadır. Araştırma bağlamında incelenen tüm web sitelerinde yönetim bilgileri yer almaktadır. Otizm konulu vakıf, örgüt ve toplulukların web sitelerinin çoğunda otizme ilişkin tanım yer alırken, sadece World Autism Organisation'da yer almamaktadır. Otizmli bireyin ve ailesinin ileriki yaşamında çok önemli bir yer tutan eğitim olanağı seçeneği, Tohum Otizm Vakfı, Autism Society ve ANOV'da yer almaktadır. Diğer web sitelerinde ise böyle bir seçenek bulunmamaktadır.

Otizmli bireye ailesine ya da eğitimcilere yönelik iş olanakları seçeneği Tohum Otizm Vakı, Autism Europe ve Autism Socıety'de yer almaktadır. Ancak; ODFED, World Autism Organısatıon ve ANOV'da iş olanaklarına ilişkin bir paylaşıma rastlanmamıştır. Otizmde eğitimin en önemli faktörlerden biri olması durumu vakıf, örgüt ve toplulukların web sitelerinde eğitim kurumlarının bilgilerinin yer alması açısından büyük önem taşımaktadır. Bu bağlamda incelenen web sitelerinde, Tohum Otizm Vakfı, Autism Society ve ODFED' de eğitim kurumlarının bilgilerine yer verilmişken, WAO ve Autism Europe'de böyle bir bilgi yer almamaktadır. Otizme yönelik belli başlı standartları, kuralları ve yasal hakları içeren tüzük, anayasa vb. seçeneği, incelenen web sitelerinin içinden sadece ODFED ve WAO'da yer almaktadır. Anayasa ve tüzüklerin bu sitelerde yer almasının en büyük nedeni, birinin dünya çapında bir örgüt olup vakıfları, dernekleri, federasyonları içine almasından, diğerinin ise dernekleri içinde barındıran federasyon olmasından kaynaklanmaktadır.

Yıllık faaliyet raporları, Tohum Otizm Vakfı, Autism Society ve ANOV'da paylaşılmıştır. Autism Socıety'nin sayfasında 2008 yılından itibaren veriler yayınlanmışken, Tohum Otizm Vakfı'nda 2013 yılından başlayan raporlar yer almaktadır. Otizm konusunda bilgi paylaşımı (everi, e-kütüphane) büyük önem taşımaktadır. İncelenen web sitelerinde Tohum Otizm Vakfı, Autism Socıety ve Autism Europe'da bilgi paylaşımı yapıldığ1 görülmektedir. Diğer web sitelerinde böyle bir paylaşım yer almamaktadır. Bilgi paylaşımının yapıldığı sitelerden olan Autism Society en geniş e- veri tabanına sahiptir. Otizme çok boyutlu bir bakış açısıyla baktığı geniş veri tabanına da yansımıştır. Vakıf, örgüt ve toplulukların 
üye profilleri bilgisi sadece ANOV' da yer almamaktadır. Diğer web sitelerinde bu seçenek bulunmaktadır. Basınla ilişiler seçeneği WAO'da yer almazken, diğer web sitelerinin basınla ilişkiler amacıyla basın odası bulunmaktadır.

Halkla ilişkiler faaliyetleri incelenen tüm web sitelerinde yer almaktadır. Faaliyetler; Tohum Otizm Vakfı'nda kampanyalar, etkinlikler, sosyal sorumluluk projeleri olarak, Autism Society'de blog, kampanyalar, bilinçlendirme amaçlı ulusal konferanslar, broşür ve kitapçılar, sosyal medya butonları olarak, ODFED'de basın bültenleri, etkinlikler, konferanslar, farkındalık amacıyla düzenlenen etkinlikler ve projeler olarak, WAO'da konferanslar, yürütülen proje ve etkinlikler olarak, ANOVda etkinlikler ve sosyal medya butonları olarak ve son olarak Autism Europe'da kampanyalar, haber bültenleri, yayınlar, kitapçıklar, broşürler şeklinde verilmektedir. Vakıf, örgüt ve toplulukların kimliklerinin aktarımı seçeneğinde, Tohum Otizm Vakfı, ODFED, WAO, ANOV ve Autism Europe'nın logoları web sayfalarında kullanılmış ancak öyküleri ile ilgili bir bilgiye yer verilmemiştir. Sadece Autism Society'nin logosunun öyküsü ayrıntılı bir şekilde verilmektedir. Sıkça sorulan sorular öğesi butonu Tohum Otizm Vakfı ve Autism Europe' da bir seçenek olarak yer almaktadır. ANOV'da ise yasal ve sosyal haklar butonu altında soru-cevaplardan oluşan başlık sıkça sorulan sorular seçeneğini kapsar nitelikte olduğu görülmüştür. Diğer web sitelerinde ise böyle bir seçenek bulunmamaktadır.

Haberleşme Ağı Fonksiyonu: Vakıf, örgüt ve toplulukların açıklık konumunu belirten, e-posta ile iletişim kurabilme fonksiyonu kullanımı 6 web sitesinde de bulunmaktadır. İncelenen tüm web sitelerinde e-posta adresine yer verilmektedir. Belli konulara vurgu yapan e-posta ortamları, ANOV haricinde diğer tüm web sitelerinde bulunmaktadır. Üyelik için çevrim içi form kullanımı incelenen sitelerin hepsinde bulunmuştur. İncelenen sitelerin içinde Autism Society ve ODFED' de ziyaretçi anketi indeksine rastlanmaktadır. Diğer sitelerde böyle bir seçenek bulunmamaktadır. Vakıf, örgüt ve toplulukların temsilcisi ile gerçekleştirilecek eş zamanlı görüşme seçeneği, Autism Society ve Autism Europe'da yer alırken diğer sitelerde böyle bir seçenek bulunmamaktadır. İncelenen web sitelerine üye olan diğer kullanıcılarla eş zamanlı görüşme 
sadece WAO'da yer almaktadır. Ziyaretçi defteri, Autism Society ve ODFED'de bulunmaktadır. İncelenen diğer web sitelerinde böyle bir özellik bulunmamaktadır.

Kampanya Fonksiyonu: Web sitelerinin hiçbirinde ana sayfalarında zamansızca çıkan pop-up, banner vb. unsurlarına rastlanmamıştır. Sosyal sorumluluk kampanyalarının aktarımı, WAO ve ANOV'da yer almazken incelenen diğer web sitelerinde bu fonksiyon yer almaktadır. Eğitim kampanyalarının aktarımı fonksiyonu ise Tohum Otizm Vakfı, Autism Society ve Autism Europe'de rastlanmaktadır. İncelenen diğer web sitelerinde bu fonksiyonun aktarımına rastlanmamıştır. Web sayfalarında yer alan logo, ekran koruyucu, duvar kâğıdı vb. gibi materyallerin indirilmesi seçeneği hiçbir web sitesinde bulunmamıştır. İncelenen diğer sitelerin etkinlikleri ve diğer materyallerinin indirilebilir özellikte olduğu görülmüştür.

\section{2) Web Sitelerinin Sunumu Özellikleri}

Web sitelerinin sunumu, görsellik, erişilebilirlik, gezilebilirlik ve güncellik özellikleri kapsamında incelenmiştir. Aşağıda yer alan tabloda veriler sunulmaktadir.

Tablo 2. Web Sitelerinin Sunumu Özellikleri

\begin{tabular}{lcccc}
\hline & Görsellik & Erişilebilirlik & Gezilebilirlik & Güncellik \\
\hline Tohum Otizm Vakfı & 5 & 4 & 2 & 0 \\
Autism Society & 5 & 4 & 5 & 0 \\
ODFED & 3 & 4 & 3 & 0 \\
WAO & 1 & 3 & 3 & 0 \\
ANOV & 4 & 2 & 3 & 0 \\
Autism Europe & 4 & 4 & 1 & 0 \\
Ortalama & 3,5 & 3,5 & 2,8 & 0 \\
Aralık & $0-3$ & $0-5$ & $0-5$ & $0-6$ \\
\hline
\end{tabular}

Görsellik Özelliği: Araştırma kapsamında incelenen kâr amacı gütmeyen örgütlerin içinden Tohum Otizm Vakfl, Autism Society ve Autism Europe' da grafik kullanımına rastlanmıştır. Ancak diğer web sitelerinde grafik kullanımına rastlanmamıştır. Web sitelerinin daha çekici hale gelmesine olanak sağlayan çerçeve kullanımının tüm web sitelerde 
kullanıldığı görülmüştür. Kayan sayfa kullanımına sadece Tohum Otizm Vakfi, ANOV ve ODFED ve Autism Society' de rastlanmıştır. İncelenen web sitelerinde, ses kullanımına sadece ANOV'da rastlanmıştır. Ses kullanımı, radyo programında kendini göstermektedir. Video seçeneği WAO harici diğer tüm web sitelerinde kullanılmaktadır. Animasyon kullanımına ise Tohum Otizm Vakfı, Autism Society ve Autism Europe'da rastlanmıştır. Buralarda animasyon kullanımı, halkla ilişkiler faaliyetleri kapsamında bilgilendirmek amacıyla kullanılmaktadır.

Erişilebilirlik Özelliği: Web siteleri erişilebilirlik fonksiyonu bağlamında incelendiğinde tüm sitenin metin halinde sunulabilirliği özelliğine tüm web sitelerinde rastlanmıştır. Dokümanların metin halinde indirilmesi ve yazılması işlevine sadece ANOV'da rastlanmamıştır. WAP/PDA kullanımı ile siteye ulaşım özelliği araştırma kapsamında incelenen tüm web sitelerinde yer almaktadır. Web sitelerinin yabancı dile çeviri özelliğine $W A O$ ve $A N O V^{\prime}$ da rastlanmamıştır. İncelenen web sitelerinden Tohum Otizm Vakfı ve ODFED'in İngilizce çevirisi bulunmaktadır. Ancak ikisinde de aktif olarak kullanılmamaktadır. Autism Society'de ise yabancı dil çevirisi İspanyolca seçeneği olarak kendini göstermektedir. Burada da tüm sitenin çevirisi yapılmamaktadır. Belli başlıklar çevrilmektedir. Autism Europe ise Fransızca dil seçeneği tek aktif web sitesidir. Görme bozukluğu olanlar için yazılım seçeneğine ise hiçbir web sitesinde rastlanmamıştır.

Gezilebilirlik Özelliği: Yapılan araştırma kapsamında incelenen web sitelerinin tümünde gezilebilirlik ipuçlarına rastlanmıştır. Arama motoru kullanımı, Autism Society, ODFED ve WAO ‘da bulunmuştur. ODFED ve Autism Society'de iki arama motoru bulunurken, WAO'da tek arama motoru olduğu saptanmıştır. Ana sayfa ikonunun sayfaların alt bölümünde bulunması işlevine ODFED ve Autism Europe harici diğer web sitelerinde rastlanmıştır. Sabit metin çubuklarının; Autism Society ve ANOV'da web sayfasının alt kısmında yer aldığına rastlanmıştır. Diğer web sitelerinde böyle bir seçeneğin varlığına rastlanmamıştır. Site haritası kullanımı ise sadece Autism Society ve ODFED web sayfalarında tespit edilmiştir. 
Güncellik Özelliği: Araştırma kapsamında incelenen otizm konulu kar amacı gütmeyen örgütlerin hiçbirinin web sayfasında herhangi bir güncelleme bilgisine rastlanmamıştır.

\section{Sonuç ve Öneriler}

Günümüz bilgi toplumunda internetle birlikte değişen ekonomi, politika, sosyo-kültürel etmenler hayatın tüm alanlarının değişim ve gelişim göstermesine neden olmuştur. İnternet ortamı sunduğu yeniliklerle bireyleri etkilediği gibi tüm sektörleri de etki altına almıştır. Halkla ilişkiler de bu durumdan etkilenen alanlar arasında yer almaktadır. Web ortamının etkileşim özelliği, halkla ilişkilerin hedef kitleleriyle interaktif iletişime girmeleri bakımından önemli bir unsurdur. Kurum/kuruluşlar tanıtım ve tanıtma faaliyetlerini web siteleri üzerinden yürütebilmekte, üstelik hızlı, ekonomik ve interaktif özelliği sayesinde hedef kitlelerinin ihtiyaçlarına daha iyi bir biçimde cevap verebilmektedirler.

Araştırmanın amacı doğrultusunda günümüzün ve geleceğin büyük bir sorunu olan otizmin ne olduğu, erken yaşta fark edilmesinin neden önemli olduğu, ailelerin ne gibi zorluklar yaşadığı ve beklentileri, eğitimler ve farkındalık çalışmalarının duyurulması büyük bir önem taşımaktadır. Bu nedenle otizmle ilgili çalışan örgütlere büyük iş düşmektedir. Bilgi iletişim teknolojilerinin ürünü olan web sitelerinde verilen bilgiler yukarıda anlatılanların gerçekleşebilmesi noktasında önemlidir. Araştırmanın evren ve örneklemini oluşturan ve otizmle ilgili çalışan örgütlerin web siteleri Dünya ve Türkiye bazında halkla ilişkiler perspektifinden incelenmiştir.

İncelemeler neticesinde, Autism Society ve Autism Europe'nın Tohum Otizm Vakfı ve ANOV'a göre e- veri tabanlarının ve kampanyalarının aktarılması ve duyurulması noktasında daha çok önem verdikleri görülmüştür. Özellikle Autism Society'nin web sayfasındaki online kaynak veritabanının, diğerlerine göre en gelişmiş olduğuna rastlanmıştır. Web sitesi içerisinde anlattığı her bir konuyla ilgili linkler vererek bu kaynaklara yönlendirme seçenekleri bulunmaktadır. Aynı zamanda topluluğun üyelerinin, başkalarıyla etkileşime girmesi, destek olması ve deneyimlerini paylaşması için alanlar sunmaktadır. Autism Society'nin yönlendirdiği sayfalar arasında; otizmli ailelerin çocuklarıyla 
birlikte zaman geçirebileceği "Duyu Dostu Filmler" programı, ücretsiz dersler, otizmle yaşam serisi yer almaktadır. Tohum Otizm Vakfı'nda bu kaynaklara ulaşmak için site içinde gezinti yapmanız gerekmektedir. Tohum Otizm Vakfının yönlendirdiği sayfalarda tohum otizm eğitim portalı en kapsamlı olanlarındandır. Burada otizme yönelik ücretli ücretsiz eğitim olanakları, yayınlar yer almaktadır.

Autism Europe ise kampanyalarının aktarımı konusunda başarılı sayılabilecek bir web sitesine sahip olduğu görülmüştür. Bu örgütün yürüttüğü projelerin en kapsamlısı; “Otizm İçin Engelleri Kaldırın" sloganıyla yürütülen kampanyadır. Web sitesinde kampanyaya ilişkin manifesto, kullanılan araçlar, hedef kitlenin nasıl destek olabileceği ayrıntılı bir biçimde verilmektedir. Yayınladıkları manifestoda, öncelikli olarak durum analizi yapılmakta, daha sonra anahtar mesajlar, kampanyanın hedefleri, önemli eylemler ve tarihleri, logo ve öyküsü, kampanyada kullanılan görseller, kampanyanın sosyal medya stratejisi, basın bülteni, bağış fikirleri yer almaktadır. Bunlarda web sitesinde indirebilir ve yazdırılabilir seçenekte bulunmaktadır. Autism Europe'da bunların dışında bir de kendi yayınları bulunmaktadır. LINK Dergisi Avrupa ve Dünya çapında otizm alanındaki gelişmeler, iyi uygulamalar, projeler ve organizasyonla hakkında bilgiler içermektedir. Bu derginin arşivi indirilebilir özelliktedir.

ANOV'da ise daha çok kendi yaptıkları eğitimlerin tanıtımları, okulda düzenledikleri etkinlikler ve medyada nasıl yer aldıkları web sitesinde göze çarpmaktadır. Tohum Otizm Vakfı, kampanya ve projelerin aktarımı konusunda Autism Europe'ya göre daha dar kapsamlı kalmıştır. Düzenledikleri etkinliklerin ve projelerin görselleri, hedef kitlelerin kim olduğu yer almaktadır.

World Autism Organısatıon ve ODFED yayınladıkları tüzük ve anayasa ile dikkat çekmektedir. Her ikisi de genellikle otizme politik anlamda paydaşları ve bireyleri destek olmaya çağırıcı bir içerikle karşımıza çıkmaktadır. Önemli tarihler, otizme yönelik istihdam olanaklarına, eğitim olanaklarına nasıl ulaşabilecekleri özellikle ODFED'in web sitesinde ayrıntılı olarak yer almaktadır. Özellikle ODFED otizm konusunda ailelere yol haritası sunmakta olduğu görülmüştür. Ayrıca bu iki örgüt, sitelerini genellikle fon sağlama amacıyla 
kullandıkları görülmektedir. Özellikle WAO bu işi kendine önemli bir görev edindiği görülmektedir.

Autism Society ve Autism Europe'nın ANOV ve Tohum Otizm Vakfı'na göre e- veri tabanı sağlaması, internet ortamının interaktifliğini kullanması, kampanyalarının daha geniş hedef kitlelere hitap ediyor olması yönleriyle ayrılmaktadır. Autism Society ve Autism Europe'nin halkla ilişkiler tanıtma faaliyetlerini daha aktif kullandıkları görülmüştür. Puanlamalarda çok büyük farklılıklar gözlenmemektedir. Ancak; Autism Society ve Autism Europe'nın web sitelerinde otizme yönelik bütüncül bir bakış açısı olduğu gözlenmiştir. Eğitim, sosyal destek, yayınlar, interaktif kullanım bu farklılıklardan en göze çarpanlarıdır. Kurumsal tarih, vizyon, misyon, e-postanın varlığı, yönetici bilgileri, eğitim olanakları ile ilgili bilgiler bakımından ise bu siteler arasında bir farklılık gözlenmemiştir.

Sonuç olarak, özellikle Türkiye bazında yer alan Tohum Otizm Vakfı ve ANOV'un kampanya ve etkinliklerinin duyurulması konusunda daha aktif olmaları, hedef kitlelerini daha geniş tutmaları, internetin aktifliğini daha işlevsel kullanmaları bu denli önemli bir konunun duyurulması ve bilinirliliğinin artması açısından önem taşımaktadır. Sağlığın ve eğitimin bir insan hakkı olması, otizmin gelecekteki bireyleri ciddi boyutlarda etkileyecek olması, konunun aciliyetle gündeme gelmesi ve farkındalık çalışmalarının haklar çerçevesinde tartışılıp duyurulması açısından önemlidir. Bu konuda ülkemizde yapılan 2016-2019 ulusal otizm eylem planında yer aldığ1 (http://www.resmigazete.gov.tr) gibi tüm kurum/kuruluşların desteği bu konunun duyurulması açısından büyük önem taşımaktadır. Ancak duyurulması tek başına yeterli olmamakla birlikte, bu sorumluluğu sadece kar amacı gütmeyen örgütlerin web sitelerine bırakmakta yanlış bir stratejidir. Sağlığın bir insan hakkı olduğu düşüncesinden yola çıarak herkesin eşit sağlık, eğitim alma hakkı çerçevesinde STK, özel kurum/kuruluşlar, devlet politikaları, medyaya büyük sorumluluk düşmektedir. Önemli olan bunların tek tek bir şeyler yapması ve otizme tek taraflı bakması değil, hepsinin birlikte çalışıp otizme çok boyutlu bakmasıyla birlikte farkındalık ve bilinçlenme gerçekleşecektir. Bu durum web sitelerine yansıdığı takdirde tam anlamıla başarı sağlanabilecektir. 


\title{
EXTENDED ABSTRACT
}

\section{The Web Sites of Nonprofit Organizations That Deal with Autism in The World and Turkey: A Comparative Study from The Perspective of Public Relations}

\author{
$*$ \\ Nilay Başok - Gül Coşkun Değirmen - Miraç Pınar Mert
}

Ege University

In the scope of the study, firstly the use of the website in the field of public relations is explained. After this, it shows how to autism organizations websites use perspective by public relations. Autism is known as a complicated defect in one's neurobehavioral which occurs natal or in his/her early life stages (https://www.tohumotizm.org.tr). According to CDCP's (Centers for Disease Control Prevention) report in 2014, one out of every 68 newborn diagnose with autism around the world. Early diagnosis is significant in terms of starting education and improving their social skills.

Autism has become widespread around Turkey and all over the world because the problem in its early diagnosis process. At this point, nonprofit organizations play a key role in awareness of the autism.

Non-profit organizations can advertise their values through websites which is a part of internet tools. Moreover they share specific information about autism which can create awareness among society and mobilize them by their websites. Institutions which work on autism (as non-profit organization) use their websites on the purpose of fund-rising. Receiving bequest via websites is directly associated with corporate image and reputation. In the part of literature, the study has focused on how organizations which work in autism can be more effective in their websites.

In the research part of study Federation of Autism Associations which takes place in Turkey and the official member of World Autism 
Organization, Autism Society which the member of World Autism Organization, and Tohum Autism Association (the supporter of Federation of Autism Associations) has been examined as sample. However, Autism Europe's which takes place in Belgium and Anatolian Foundation of Autism's (ANOV- takes place in Turkey) websites have been chosen for comparing study and gathering different data.

This part put forward that how non-profit organizations disseminate information and presenting their mission, websites' visual and auditory elements, sharing information for their target groups, offers the being active to the audience by their websites in the world and Turkey.

The findings have shown that Autism Society and Autism Europe attach important to more than ANOV (Anatolian Foundation of Autism) and Tohum Autism Association in the point of usage of database and announce of information or campaigns in their websites. Specifically, database which takes part in the website of Autism Society is more sophisticated than other non-profit organizations' websites. Furthermore, there are many links about the topic which belong the blog in the website and many pages which help to members of society in order to being interactive, support and sharing their experiences by the website.

Among the redirecting pages of Autism Society's there is specific movie, "Sensory Friendly Film" which parents can spend time with their autistic child/children, have free courses and live with autism series have been headed.

In the Tohum Autism Association's website the user has to surf for reaching these sources (video programs, free courses or book series etc.). However, Tohum Autism Association's website is the most comprehensive in terms of education materials among all websites which have been examined in the study. The web page also has many opportunities for having free or paid education and publishing for autism.

Autism Europe's web site is enviable in terms of transferring campaigns' information. The most comprehensive campaign which runs by this non-profit organization is "Break barriers together for autism". In this campaign the institution helps to society for being accessible.

Although educational promotional, events (organized at school) and coverage information have been mostly found in ANOV's (Anatolian Foundation of Autism) website, in the website of World Autism 
Organization and Federation of Autism Associations rules has been pointed out. Both websites have been remarkable in the way of sharing information with their stakeholders and individuals to political support.

As a result, it is suggested that being able to active during campaign and event sharing, enhancing the target groups and functionalizing the websites of Tohum Autism and Anatolian Foundation of Autism (works in Turkey) in order to expand awareness about autism. Also, it is necessary to discuss about autism because health and education is a human right and this disadvantage treats next generations. Because of this, it is very significant to argue on the awareness and legislative regulations on autism.

The issue of autism has to be supported by non-profit organizations in order to create or expand awareness as in the action plan which has been put forward between 2016-2019 by government (http://www.resmigazete.gov.tr). However, it is not only enough to announce the problems about autism in non-profit organizations' websites but also all kind of institutions, government policies, NonGovernmental Organizations and media should take responsibility for awareness of the autism.

\section{Kaynakça / References}

Anadolu Otizm Eğitim ve Mücadele Geydirici Vakfı, 06 Aralık 2017 tarihinde http://www.anadoluotizm.org/ adresinden alınd.

Autism Europe, 06 Aralık 2017 tarihinde http://www.autismeurope.org / adresinden alınd.

Autism Society, 06 Aralık 2017 tarhinde https://www.autism-society.org/ adresinden alınd.

Balay, B. (2002). İnternet'in halkla ilişkiler aracı olarak kullanımı. İstanbul Üniversitesi İletişim Fakültesi Dergisi, 12, 847-856

Başok, N. ve Değirmen, C. G. (2014). Proje yönetimi halkla ilişkilerde tutarlı, özgün, sürdürülebilir uygulamalar. Ankara: Nobel Yayınları.

Gibson, K. R., Margolis, M., Resnck, D. ve Ward, S. (2001). Election Campaigning on the WWW in the US and UK:A Comparative Analysis. Party Politics. 9(1), 47-76. 
Gölönü, S. (2006). Gelişen teknolojiler, öğrenen örgütler ve halkla ilişkiler. Selçuk Üniversitesi İletişim Fakültesi Dergisi, 4(3), 73-81.

Güçdemir, Y. (2002). Halkla ilişkilerde yeni iletişim teknolojilerinden internetin kullanımı. İstanbul Üniversitesi İletişim Fakültesi Dergisi, 14, 387-396.

http://t24.com.tr / Erişim Tarihi:16.11.2017

Kaplan, G. (2009). İnternetin halkla ilişkiler ve tanıtım aracı olarak kullanımı: Tüketici örgütlerinin web sayfaları üzerine bir araştırma. Akdeniz Üniversitesi İletişim Fakültesi Dergisi, 11, 71-120.

Okay, A., Okay, A. (2001). Halkla ilişkiler kavram strateji ve uygulamaları. İstanbul: Der Yayınları.

Otizm Dernekler Federasyonu, 14 Kasım 2017 tarihinde http://www.odfed.org/adresinden alındı.

Özel, P. A. ve Sert, Y. N. (2015). Dijital halkla ilişkiler kavram ve araçları. İstanbul: Derin Yayınları.

Resmi Gazete, 15 Kasım 2017 tarihinde http://www.resmigazete.gov.tr/ adresinden alınd.

Sayımer, İ. (2012). Sanal ortamda halkla ilişkiler. İstanbul: Beta Yayınları.

Tarhan, A. (2007). Halkla ilişkilerde tanıma ve tanıtma aracı olarak internet: Belediyelerin web sayfaları üzerine bir analiz. Selçuk Üniversitesi İletişim Fakültesi Dergisi, 4, 77-95.

Taş, E. ve Kestellioğlu, G. (2011). Halkla ilişkilerde internetin yeri ve önemi. KSÜ İ̈BF Dergisi, 1, 73-92.

Tohum Otizm Vakfı, 06 Aralık 2017 tarihinde https://www.tohumotizm.org.tr/ adresinden alındı.

Tübitak, 16 Kasım 2017 tarihinde http://www.bilimgenc.tubitak.gov.tr/ adresinden alındı.

World Autısm Organısation, 06 Aralı 2017 tarihinde http://worldautismorganisation.com / adresinden alınd1.

Yassıbaş, U. (2015). Otizm Spektrum Bozukluğu Olan Çocuğa Sahip Anne Babaların Yaşam Deneyimlerine Derinlemesine Bakış (Yayınlanmamış Yüksek Lisans Tezi) Eskişehir Anadolu Üniversitesi Eğitim Bilimleri Enstitüsü. Eskişehir. 
Yeygel, S. ve Temel, A. (2006). İşletmelerin kurumsal imajlarının hedef kitlelere iletilmesinde bir araç olarak kurum web siteleri. II. Ulusal Halkla İlişkiler Sempozyumu: 21. Yüzyılda Halkla İlişkilerde Yeni Yönetimler Sorunlar ve Çözümler. Kocaeli Üniversitesi İletişim Fakültesi. Kocaeli.

\section{Kaynakça Bilgisi / Citation Information}

Başok, N., Coşkun-Değirmen. G., ve Mert, P. M. (2018). Dünya ve Türkiye'de otizmle ilgili çalışan kar amacı gütmeyen örgütlerin web sitelerinin halkla ilişkiler perspektifinden karşılaştırmalı incelemesi. OPUS-Uluslararası Toplum Araştırmaları Dergisi, 11(18), 321-344. DOI: 10.26466/opus.541151 